\title{
Konsep Wahyu Dalam Menguatkan Jiwa Nabinya : Studi kajian Surat Al- Muzammil 1-10
}

\author{
Indra Ambiya ${ }^{1}$, Wildan Taufik ${ }^{2}$ \\ 1,2Pascasarjana Ilmu Al-Qur'an dan Tafsir UIN Sunan Gunung Djati Bandung \\ Email: Indra.ambiya@gmail.com,wildantaufik@uinsgd.ac.id
}

\begin{abstract}
Various life problems faced by humans often lead to despair in life, when the soul feels weak, then Satan will be easy to fool people, so that they take shortcuts in dealing with various problems that befall them. Al-Qur'an provides guidance and guidance on how humans deal with various problems they face, among the forms of guidance of the Koran, namely God shows a noble figure in facing various challenges, bullying and various other pressures given by unbelievers against him so as to make himself and his soul covered in anxiety. By going through library research and analyzing it using the tahlili method, there are seven ways in which the Qur'an strengthens its prophetess in dealing with these problems: first, the midnight prayer; second, strengthen the soul by reading the Qur'an in tartil; third, establishing clear directions and goals; fourth, always remember God; fifth, having only trust in Allah; sixth, be patient in facing every test that befalls; and seventh, have confidence in God's promises
\end{abstract}

Keywords: al-Muzammil , Concept, soul,

\begin{abstract}
ABSTRAK
Berbagai persoalan hidup yang dihadapi manusia seringkali memunculkan sikap putus asa dalam hidup, saat jiwa merasa lemah, maka syetan akan mudah untuk mengelaabui manusia, sehingga mengambil jalan pintas dalam menghadapi berbagai persoalan yang menimpanya. Al-Qur'an memberikan bimbingan dan tuntunan bagaimana manusia menghadapi berbagai persoalan yang dihadapinya, di antara bentuk bimbingan al-Qur'an, yaitu Allah perlihatkan sosok yang mulia dalam menghadapi berbagai tantangan, bullyan dan berbagai tekanan lainnya yang diberikan oleh orang-orang kafir terhadap beliau sehingga membuat diri dan jiwa beliau berselimut dalam kegelisahan. Dengan melalui Library research (kajian studi kepustakaan) kemudian menganalisisnya dengan metode tahlili, Ada tujuh cara bagaimana AlQur'an menguatkan nabinya dalam menghadapi berbagai persoalan tersebut: pertama, sholat tahajud; kedua, menguatkan jiwa dengan membaca al-Qur'an secara tartil; ketiga, membangun arah dan tujuan yang jelas; keempat, senantiasa mengingat Allah; kelima, memiliki sikap tawakal hanya kepada Allah keenam, bersabar dalam menghadapi setiap ujian yang menimpa; dan ketujuh, memiliki keyakinan akan janji Allah.
\end{abstract}

Kata kunci: al-Muzammil, jiwa, Konsep,

\section{PENDAHULUAN}

Setiap manusia dalam kehidupannya senantiasa mendapatkan ujian, karena hakikat hidup ini merupakan ujian, sebagaimana dalam firman-Nya:

Artinya: "Dan sungguh kami benar-benar akan menguji kalian dengan berupa rasa takut, kelaparan, kekurangan harta, kematian jiwa, gagal panen, dan berbahagialah bagi orang-orang yang shabar." (Q.S. Al-Baqarah: 155).

Ujian merupakan bentuk pembuktian, apakah hamba itu semakin dekat dengan Sang Penciptanya, atau justru dengan ujian itu menjadikan manusia berputus asa dari keberadaan dengan Sang Penciptanya. Berbagai persoalan dan tekanan hidup seringkali membuat seseorang stress dan depresi, bahkan tidak

* Copyright (c) 2020 Indra Ambiya dan Wildan Taufik

This work is licensed under a Creative Commons Attribution-ShareAlike 4.0 International License. 
sedikit yang mengakhiri hidup dengan cara bunuh diri, dikarenakan tak mampu keluar dari beban berat yang dihadapi.

Banyak faktor yang memicu munculnya stress, mulai dari tuntutan gaya hidup, sibuk dengan berbagai aktifitas dan pekerjaan yang membuat dirinya tertekan, persaingan ekonomi, permasalahan keluarga, dan berbagai faktor lainnya.

Pada bulan Maret tahun 2019, manajer JKT 48 tewas dengan cara gantung diri di kamar mandi, menurut analisa bahwa perbuatan itu dilakukan karena tekanan berat yang menimpanya (Santoso, Asiah, \& Kirana, 2018).

Kasus lainya menimpa seorang pegawai negri sipil yang menjabat sebagai bendahara, melakukan bunuh diri. Ia menulis surat bahwa selama dalam pekerjaannya ia senantiasa mendapatkan tekanan dari atasannya yang berkaitan dengan keuangan (Santoso et al., 2018).

Hal diatas hanya contoh kecil bahwa tekanan yang dihadapi seseorang bisa berakibat buruk, bahkan kematian. Rasulullah seorang manusia yang sama dengan manusia pada umumnya, beliau merasakan kebahagiaan, kesedihan, tawa, tangis, dan lain sebagainya. Pada masa awal dakwah, beliau merasakan tekanan yang begitu berat dan besar dalam jiwanya. Tekanan itu membuat beliau terganggu secara psikologis. Awal mula tekanan psikologis itu muncul setelah Rasulullah menyatakan dirinya sebagai seorang utusan Allah, membawa kaumnya dari kegelapan menuju cahaya. Ibnu Katsir menjelaskan dalam kitabnya, kaum Quraisy berkumpul disebuah tempat yang bernama Dar ad-Dadwah, mereka memperbincangkan tentang nama penyebutan (Rasulullah), agar orang-orang enggan untuk berbicara dengan beliau. Ada yang mengusulkan memberikan nama dengan sebutan dukun, orang gila, dan tukang sihir. Namun semua hal itu tersanggah, karena Rasulullah bukanlah seorang dukun, bukan orang gila dan bukan tukang sihir. Pembicaraan tentang pribadi Rasulullah ini sampai kepada diri beliau, hal itu membuat beliau tertekan dan menutupi diri (Agung, Ramdhani, \& Zuhri, 2020).

Ada dua tekanan yang membuat hati beliau sibuk dan tertekan, yakni:. beratnya beban dakwah yang harus beliau pikul, tugas ini membutuhkan kekuatan mental; serta dasyatnya tipu daya musuh untuk menghancurkan misi dakwah yang dibawa oleh Rasulullah menyebabkan Nabi Muhammad mengalami kegelisahan, kecemasan, ketakutan dan kekhawatiran.

Dalam kondisi tersebut, Nabi merenungkan hal yang sedang dialaminya sambil menyelimuti diri dengan kain menutupi badannya. Saat itu turunlah Malaikat Jibril menyampaikan wahyu surat alMuzammil ayat 1-10:

"Hai, orang yang berselimut, bangun untuk shalat di malam hari, dan sisakan sedikit waktu untuk tidur, yaitu separuhnya atau kurang dari itu, atau lebih dari separuhnya dan bacalah al-Qur'an secara perlahan. Sesungguhnya, Kami akan menurunkan ucapan yang berkualitas kepadamu. Sesungguhnya bangun malam itu lebih kuat untuk mengisi jiwa, dan bacaan pada waktu itu akan lebih membekas dalam jiwa. Sesungguhnya, pada siang hari kamu sibuk dengn berbagai urusan yang panjang, sebutlah nama Tuhanmu dan beribadahlah kepada-Nya dengan sepenuh hati, Allah Tuhan Penguasa Timur dan Barat, tiada Tuhan selain-Nya, maka jadikanlah Allah sebagai penolong, shabarlah terhadap ucapan mereka dan tinggalkan mereka dengan cara yang baik".(Q.S. AlMuzammil : 1-10).

Seakan ayat-ayat diatas mengisyatkan kepada Rasulullah, "Hai Muhammad, janganlah engkau cemas, janganlah engkau gelisah, hadapi tantangan yang diberikan oleh musuh kepadamu, namun kuatlah jiwa dan fisikmu dengan berbagai perintah yang telah Aku perintahkan kepadamu."

Tekanan demi tekanan yang dialami oleh Rasulullah Saw tidak membuat diri beliau stress dan depresi, namun beliau mampu dengan tegar dalam menghadapi berbagai penekanan yang dilakukan oleh kaumnya. Wahyu membimbing beliau sehingga bisa keluar dari berbagai permasalahan yang dihadapi. 
Bagaimana wahyu membimbing dalam menguatkan jiwa beliau untuk menghadapi berbagai tantangan dan tekanan dari musuh-musuhnya? Hal ini perlu dipelajari bagi manusia zaman ini, mencontoh perilaku Rasulullah, agar tidak mudah menyerah dan putus asa dalam mengahadapi berbagai persoalan dalam hidup.

\section{METODE PENELITIAN}

Metode penelitian yang penulis gunakan yaitu penelitian kualitatif (Sugiyono, 2013) melalui Library research (kajian studi pustaka) (Prastowo, 2011), yaitu pengumpulan data atau bahan-bahan yang ada hubungan dengan tema pembahasan serta permasalahannya, yang diambil dari berbagai sumber kepustakaan, kemudian dianalisis dengan metode tahlili, yaitu metode penafsiran ayat-ayat alQur'an yang dilakukan dengan cara memaparkan semua aspek yang terkandung dalam ayat-ayat alQur'an yang ditafsirkan dan mendeskripsikan uraian makna yang terkandung didalamnya. Untuk pendukung penelitian ini, penulis menggunakan sumber utama kitab tafsir yaitu Tafsir Ibnu Katsir karya Abu al-fida'I Isma'il bin umar bin katsir, Tafsir al-Misbah karya M.Quraish Shihab, Tafsir Tarikh Nuzul alQur'an karya Muhammad Ra'fat.

\section{HASIL DAN PEMBAHASAN}

Emosi negatif yang muncul pada diri seseorang seperti rasa sedih berlebihan, kebencian kepada seseorang, iri dengan kesuksesan orang lain, putus asa dalam menghadapi persoalan, kecemasan, tidak pernah bersyukur dengan apa yang didapatkan, dan lain sebagainya, jika hal tersebut dibiarkan akan berdampak lemah dan mengganggu sistem kekebalan tubuh pada diri orang tersebut bahkan bisa berdampak muncul stress dan depresi.

Penelitian Katon dan Sullivan (1990), mengatakan: "15 sampai 33 persen pasien yang datang ke dokter, disebabkan karena menderita penyakit tekanan emosional seperti ketakutan yang berlebihan terhadap sesuatu, kekhawatiran mengenai sesuatu, rasa frustasi, merasa tidak aman, stress dan lain sebagainya. Hal itu yang menjadi penyebab munculnya berbagai penyakit pada tubuh seperti sariawan, penyakit jantung, sulit untuk tidur, usus buntu, diabetes, gangguan pencernaan, bahkan kanker (Lumongga, 2016).

Saat ini yang harus mendapatkan perhatian serius, berkaitan dengan masalah kesehatan mental, di antaranya depresi yang dialami penduduk di negara-negara berkembang. Bahkan WHO memprediksi bahwa pada tahun 2020 penyebab kematian terbesar kedua setelah penyakit jantung adalah penyakit mental dan depresi (Lumongga, 2016).

Penyakit mental seperti stress dan depresi bisa mengenai berbagai usia, anak-anak, remaja, pemuda dan juga para orang tua. Dikarenakan berbagai akibat disebabkan olehnya, semakin maju dunia, semakin berkembang negara, stress dan depresi menjadi acaman besar bagi manusia.

Rasulullah merupakan manusia biasa, sama dengan manusia pada umumnya, beliau merasakan lapar, merasakan haus, merasakan bahagia, merasakan sedih dan merasakan segala hal yang dialami manusia pada umumnya, sebagaimana ditegaskan dalam al-Qur'an:

Artinya: "Katakanlah hai Muhammad, sesungguhnya aku pun manusia, sama seperti kalian, hanya saja diwahyukan kepadaku bahwasanya Tuhan kalian adalah Tuhan yang satu..." (Q.S. Al-Kahfi: 110).

Jika manusia lainnya merasakan tekanan saat orang-orang di sekitarnya mencela dan mencaci dirinya, begitu pun dengan Rasulullah, yang merasakan tekanan akan cacian dan celaan dari masyarakat 
sekitar. Akan tetapi kondisi beliau segera membaik dan diperkuat dengan bimbingan wahyu langsung dari langit.

Dalam surat al-Muzammil, Allah memberikan penguatan jiwa kepada Rasulullah Saw, agar beliau kuat dalam menghadapi berbagai tekanan yang datang dari masyarakat kafir Quraisy. Allah turunkan surat al-Muzammil sebagai penguat jiwa akan hati Rasul-Nya yang merasakan kerapuhan jiwa dalam menghadapi tekanan kaumnya.

Allah SWT memulai penguatan jiwa Rasulullah dengan memanggil beliau dengan panggilan yang lembut dan halus, "Wahai yang berselimut", seruan ini merupakan seruan kelembutan Allah kepada NabiNya, serta merupakan cara Allah menguatkan Nabi-Nya, bahwa ia tidak sendirian dalam menghadapi tekanan masyarakatnya. Ada Allah yang akan membersamainya untuk menguatkan jiwanya, sebagaimana penguatan Rasulullah kepada Abu Bakar saat Abu Bakar menangis di dalam gua Tsur, "Janganlah engkau bersedih, sesungguhnya Allah bersama kita" (Q.S. At-Taubah: 40).

Saat ada seseorang yang mengalami sebuah permasalah berat yang menekan jiwanya, kehadiran kawannya untuk mau mendengarkan curhatannya bisa menjadi cara untuk keluar dari permasalahannya.

Kata (المزمل) "al-Muzammil" berasal dari kata (الزمل)"Az-zamlu”, yang artinya beban yang berat. Seorang yang kuat dinamakan dengan (ازميل) “izmil”, karena beban yang berat mampu dipikulnya. Ia juga memiliki arti menggandeng, sehingga muncul kata "Zamil", artinya teman akrab yang bagaikan bergandengan (Yahya, 2019).

Saat Nabi Muhammad Saw mendapatkan tekanan dan beban berat yang menimpa beliau, Allah menyeru nabi-Nya untuk segera bangkit menatap masa depan penuh dengan keoptimisan dalam menjalaninya.

Kata (قم) qum diambil dari kata "qawama" kemudian berubah menjadi "qaama", yang secara umum diartikan dengan makna melakukan segala sesuatunya dengan penuh kesempurnaan dari berbagai aspeknya (Yahya, 2019).

Cara al-Qur'an dalam menguatkan Jiwa Rasulullah saat beliau menghadapi tekanan dan tantangan yang berat dari kaumnya, Allah jelaskan dalam surat al-Muzammil, sebagai berikut:

\section{Sholat Malam/Tahajud}

Shalat merupakan cara seorang hamba untuk mencurahkan isi hati yang dibebani berbagai persoalan dalam hidupnya. Utamanya saat dalam kondisi sujud, Rasulullah Saw bersabda: "Sujud merupakan situasi paling dekat antara seorang hamba dengan Rabbnya,maka hendaklah ia memperbanyak doa saat sujud." ( H.R. Muslim).

Pada saat siang hari, manusia disibukkan dengan berbagai aktifitas yang menyibukan dan melelahkan, sedangkan malam hari dijadikan sarana untuk mengistirahatkan tubuh dan pikiran. Pada malam hari, Allah perintahkan Rasul-Nya untuk bangun malam dan bermunajat kepada Rabbnya, karena pada malam hari itulah seorang hamba merasakan kedekatan dengan Rabbnya. Mereka mencurahkan kegelisahan-kegelisahan yang dialaminya kepada Sang Penciptanya. Curahan hati membawa ketenangan dalam jiwa mereka yang merasakan kegelisahan. Seperti dikatakan dalam sebuah hadits, "Shalat tahajud bisa menghapus dosa, menghadirkan ketenangan dan menjauhi penyakit". (HR.Tirmidzi).

Ketenangan yang didapatkan pada saat melaksanakan shalat tahajud akan membawa enrgi positif dalam diri seseorang. Dalam sebuah penelitian diungkapkan bahwa ketenangan membawa kepada ketahanan tubuh imunologik, berkurangnya resiko untuk terkena penyakit jantung, serta mengingkatkan usia harapan (Yahya, 2019). Sebaliknya, mereka yang mengalami stress sangat mudah untuk terkena infeksi, perkembangan sel kanker akan sangat mudah serta mendorong untuk meningkatnya metastasis (Putra, 2019). 
Secara teoritis, bahwa mereka yang rajin melaksanakan tahajud akan terjaga kesehatannya baik secara fisik maupun mental. Shalat tahajud yang dikerjakan secara rutin, penuh kekhusuan, serta ikhlas dalam melakukannya, akan menumbuhkan respon positif. Shalat tahajud selain memiliki nilai ibadah, akan tetapi juga penuh dengan muatan psikologis yang bisa mempengaruhi kontrol kognisi, dengan cara memperbaiki persepsi dan motivasi yang positif, dan coping yang efektif, serta emosi yang positif dapat menghindarkan diri dari stress.

Shalat tahajud memiliki banyak hikmah dan manfaat yang bisa didapatkan:

1. Berbagai macam kenikmatan yang menyejukan mata akan didapatkan bagi mereka yang melaksanakan shalat tahajud (Q.S. As-Sajdah: 16-17), tutur katanya berkualitas dan sangat berbobot (Q.S. Al-Muzammil: 5).

2. Baik di dunia maupun di akhirat, bagi yang suka melaksanakan tahajud akan memperoleh tempat yang terpuji, maqaman mahmuda (Q.S. Al-Isra': 79).

3. Bagi yang suka melaksanakan shalat tahajud, akan dihapuskan segala dosa dan keburukannya serta terhindar dari berbagai macam penyakit (H.R. Tirmidzi).

4. Tahajud akan membentuk pribadi yang optimis, tidak mudah mengeluh, tidak minder, mantap dalam menatap masa depan.

Malam hari merupakan waktu yang sangat tepat seorang hamba merasa dekat dengan Tuhan-Nya. Mereka mencurahkan segala keluhan dan permasalahan yang dihadapi kepada Rabb-Nya. Semakin ia mendekat kepada Penciptanya, semakin terasa ketentraman dan ketenangan dalam jiwanya, karena ia mencurahkan segala isi hatinya kepada penguasa alam raya ini. Semakin sering seseorang bangun pada waktu malam dan bermunajat kepada Allah, akan semakin dirasakan kekuatan jiwa dalam dirinya. Dalam sebuah hadits diriwayatkan:

"Dari Abu Hurairah semoga Allah meridhoinya, ia berkata: Rasulullah Saw bersabda: Allah Swt turun pada saat malam hari ke langit dunia di sepertiga malam terakhir, lalu berfirman: Siapa di antara hamba-Ku yang berdo'a kepada-Ku, maka Aku akan mengambulkan do'anya, siapa yang meminta kepadaKu, maka Aku akan mengabulkan permohonannya, siapa yang memohonkan ampun kepada-Ku, maka Aku pasti akan mengambulkan permohonan ampunannya." (H.R. Abu Daud No. 1120).

Sehingga shalat malam inilah yang dijadikan Allah kepada utusan-Nya sebagai sebuah amalan untuk menguatkan jiwa beliau dalam menghadapi tantangan yang berat dalam menjalankan tugasnya sebagai seorang rasul kepada semua umat manusia khususnya dan kepada umat manusia secara umum.

\section{Membaca Al-Qur'an dengan Tartil}

Al-Qur'an merupakan kitab yang diturunkan Allah kepada manusia sebagai sarana untuk mendekatkan diri, serta pembimbing dan petunjuk manusia ke arah yang diridhai Allah. Kemurnian dan keotentikannya sudah ada jaminan dari Allah Swt, sebagaimana dijelaskan dalam al-Qur'an:

"Sesungguhnya Kami telah menurunkan Al-Qur'an, dan sesungguhnya Kamilah yang senantiasa menjaganya." (Q.S. Al-Hijr: 9)."

Dr. Mustafa Mahmud, mengutip pendapat Rasyid Khalifah, mengatakan bahwa bukti-bukti keotentikan dan jaminan kemurnian al-Qur'an terdapat dalam al-Qur'an itu sendiri.

Al-Qur'an merupakan kitab suci yang seluruh kitab lainnya tak ada yang bisa menandingi al-Qur'an. Seseorang semakin mendalami ke dalamnya tak akan pernah menemukan ujungnya, karena semakin dalam pendalaman dan pengkajian al-Qur'an, maka semakin terbuka lebar dan luas ilmu yang terkandung di dalamnya. Orang yang beriman tak akan pernah merasa bosan saat berinterkasi dengan al-Qur'an, bahkan semakin cinta seseorang dengan al-Qur'an, maka semakin sulit mereka untuk jauh dari al-Qur'an. 
Hal ini merupakan bentuk kemu'jizatan al-Qur'an, bahkan keindahan dan kenikmatannya tidak hanya dirasakan oleh mereka yang menyaksikan pada saat al-Qur'an itu diturunkan, namun akan senantiasa dirasakan sampai kiamat terjadi.

Al-Qur'an sebagai sarana untuk menguatkan dan mengobati jiwa manusia yang sedang lemah atau rapuh dengan berbagai masalah yang dihadapi. Di dalam al-Qur'an dijelaskan:

"Wahai manusia, sungguh telah datang kepadamu sebuah peringatan dari Tuhan kalian, menjadi penawar/obat bagi yang memiliki penyakit di hatinya, sebagai petunjuk dan sebagai rahmat bagi orang yang beriman" (Q.S. Yunus: 57$)$. “

Allah Swt memerintahkan Nabi-Nya agar membaca al-Qur'an dengan cara yang tartil. Membaca alQur'an dengan tartil itu adalah membaca dengan pelan-pelan, tidak tergesa-gesa, serta membaca hurufhurufnya sesuai dengan kaidah bacaan al-Qur'an, sehingga mendorong untuk memikirkan makna yang terkandung di dalamnya.

Tartil itu membaca dengan fasih, jelas, terang, sehingga mendorong pendengarnya untuk memikirkan satu persatu setiap hurufnya. Oleh karena Ibnu Mas'ud melarang membaca al-Qur'an dengan tergesa-gesa, dan berkata: "Janganlah seseorang di antara kalian ingin segera sampai akhir surat, yakni bagi yang membaca dan yang mendengarkan bacaan al-Qur'an itu membawa kesejukan dan ketentramam jiwa. Ketika sampai membaca ayat tentang Allah, ia merasakan keMaha Agungan dan kemulian Allah, ketika sampai ayat tentang janji dan ancamannya, maka ia penuh dengan raja'(berharap) dan khauf (muncul rasa takut), dan membaca dengan tartil mencegah kesalahan dalam membacanya." (Abdillah, 2001).

Membaca al-Qur'an pada waktu malam lebih menguatkan pikiran dan jiwa, karena pada saat itu, manusia terbebas dari kebisingan aktifitas pekerjaaan manusia, kebisingan kendaraan, kegaduhan suara anak-anak, dan lain sebagainya. Namun pada saat di malam hari mereka akan mendapatkan ketenangan malam, kesucian alam yang akan membawa kesyahduan ketika merenungkan ayat suci al-Qur'an.

Motivasi dari Nabi Saw agar membaca al-Qur'an dengan tartil:

“Tidak termasuk kelompok kami, bagi mereka yang tidak melagukan al-Qur'an” (HR. Bukhari No. 6973).

"Wahai Abu Musa, sesungguhnya aku telah diberi seruling dari serulingnya keluarga Dawud" (HR. Bukhari No. 4660)."

Berbagai tantangan yang dihadapi Rasulullah Saw tidak membuat dirinya menjadi lemah semangat atau mundur dalam melanjutkan dakwah, karena ketenangan dan ketentraman hadir pada saat beliau berinterkasi dengan al-Qur'an. Al-Qur'an memberikan energi yang positif bagi mereka yang berinteraksi dengan al-Qur'an. Untuk itu Allah memerintahkan Nabinya bangun pada malam hari mendekat kepada Allah dengan memperlama berdiri untuk sholat dan berlama dalam sujud, setelah itu diperintahkan untuk semakin menetramkan hati melalui membaca al-Qur'an dengan cara pelan-pela dan tidak tergesa-gesa, yang akan mendorong jiwanya mendapatkan ketenangan.

\section{Membangun Arah dan Tujuan yang Jelas}

Cara Allah menguatkan Nabi-Nya yang ketiga, yaitu menjelaskan kepada beliau akan arah dan tujuan yang jelas. Mudah goyahnya seseorang, karena ia tak memiliki tujuan yang jelas dalam hidupnya. Nabi Saw memiliki konsep dan tujuan yang jelas, sehingga berbagai tekanan, celaan, dan olokan dari masyarakat, justru semakin memperkuat jiwa beliau, karena adanya arah dan tujuan yang jelas.

Al-Qur'an memberikan motivasi kepada manusia agar hidup mereka tidak hanya berjalan apa adanya, namun mesti memiliki rencana dan tujuan yang jelas. 
Beberapa ayat mendorong hal tersebut, seperti:

“Akan pergi kemanakah kalian?” (Q.S. At-Takwir: 26).

"Wahai orang yang beriman, bertaqwalah kalian kepada Allah, dan hendaklah setiap jiwa memperhatikan apa yang akan dilakukannya di esok hari, bertaqwalah kepada Allah, sesungguhnya Allah Maha mengetahui terhadap apa yang telah kalian lakukan" (Q.S. Al-Hasyr: 18)."

Prinsip dalam membangun arah dan tujuan yang jelas adalah sebagai berikut (Khusna, 2016):

1. Star Principle, yaitu dalam menetapkan arah dan tujuan, seseorang mesti memiliki landasan dan prinsip dalam bertindak dan berpikir. Jika landasan untuk mencapai sesuatunya keliru, maka akhirnya pun akan berujung pada kerugian. Sebagai contoh, jika ada seseorang yang prinsipnya jabatan, maka ia akan menghalalkan segala caranya untuk meraih jabatan tersebut. Rasulullah Saw dalam menjalani setiap perjalanan dakwahnya memiliki prinsip untuk menggapai ridha Allah, sehingga seperti apapun celaan, ejekan, dan cemoohan, mampu dihadapi karena yang beliau harapkan adalah keridhan Allah, bukan keridhaan manusia.

2. Angel Principle, yaitu perlu adanya kepercayaan melalui integritas dan kejujuran.

3. Learning Principle, yaitu memiliki prinsip untuk terus belajar, membaca dan berpikir, sehingga mampu menyempurnakan segala sesuatunya.

4. Vision Principle, yaitu tujuan yang jelas yang hendak dicapai.

Arah dan tujuan yang jelas mendorong seseorang untuk melakukan yang terbaik dalam setiap aktifitasnya, agar tercapai apa yang diinginkan. Meskipun ada gangguan yang datang tidak membuat mereka berhenti, namun terus belajar mencari solusi dari setiap permasalahan yang dihadapi.

Arah dan tujuan yang jelas membuat manusia tidak ragu dalam melangkah, karena ia sudah memiliki peta hidup yang akan dijalaninya. Berbeda dengan mereka yang tidak memiliki tujuan dan arah yang jelas dalam hidupnya, mereka akan mudah terombang-ambing bagaikan ombak, atau mengalir ke arah mana saja air itu mengalir, tak ada tujuan dan arah yang jelas yang ingin dicapai.

Maka dalam ayat ini Allah menguatkan Nabi-Nya, bahwa ia akan menerima perkataan yang berat, yaitu firman-firman Allah Swt berupa al-Qur'an. Jadikan al-Qur'an sebagai peta perjalanan yang dijadikan sebgai pedoman dalam menghadapi berbagai ragam ujian dan cobaan yang akan beliau hadapi dalam menyampaikan risalah Islam.

\section{Dzikrullah}

Dzikrullah yaitu kondisi senantiasa mengingat kepada Allah. Dzikir bukan hanya mengucapkan nama Allah di lisan atau dalam pikiran dan hati, akan tetapi termasuk juga mengingat mengenai zat-Nya, sifat-Nya, dan perbuatan-Nya, kemudian menyerahkan urusan hidup dan matinya hanya kepada Allah. Sehingga segala macam bahaya dan cobaan yang dialami tidak membuat dirinya gentar dan takut, karena semua ia serahkan kepada Allah (Sangkan, 2002).

Ada banyak fungsi ketika seseorang mengingat Allah Swt:

1. Dzikir sebagai sarana untuk mendapatkan keridhaan Allah. Semakin sering seseorang mengingat Allah, Allah akan semakin cinta kepadanya. Sebaliknya jika seseorang melupakan Allah, maka Allah pun akan melupakannya, sebagaimana dalam ayat al-Qur'an:

"Janganlah kalian seperti mereka yang melupakan Allah, sehingga Allah menjadikan mereka lupa kepada diri mereka sendiri..." (Q.S. Al-Hasyr: 19). 
2. Seseorang yang senantiasa mengingat Allah, maka akan mampu melawan gangguan atau godaan yang dibawa oleh syetan.

"Ibnu Abbas menjelaskan ketika menafsirkan kalimat "al-was was al-khannas", yaitu "Syetan mendekam berada dalam diri manusia, jika ia lupa dan lalai, syetan akan membisikan (keburukan), jika dia mengingat Allah, maka syetan akan bersembunyi."

"Dalam riwayat yang lain, Mu'tamar bin Sulaeman dari ayahnya berkata: "Diterangkan kepadaku, bahwa syetan akan meniup ke dalam hati manusia ketika dalam kondisi sedih maupun dalam kondisi bahagia, jika ia mengingat Allah, maka syetan akan bersembunyi."

3. Seseorang yang dzikir kepada Allah, dimudahkan kesulitannya dan diringankan kesusahannya, serta dihilangkan segala keburukan pada dirinya. Segala yang ada di muka bumi ini semuanya datang dari Allah, saat manusia mengingat Allah, artinya ia menjadikan Allah sebagai pelindung dan menyerahkan segala urusannya kepada Allah.

4. Dzikir kepada Allah salah satu cara untuk melenyapkan kesedihan dan keresahan dari dalam hati. Hati yang tidak pernah mengingat Allah menjadikan hatinya kering dan berkarat. Jika hati sudah kering dan berkarat, menyebabkan sulit mendapatkan cahaya ilahi, sehingga hidupnya menjadi penuh dengan kegelapan. Saat ia mendapatkan ujian kesedihan dan keresahan, tidak menjadikan dia semakin dekat dengan Penciptanya, namun justru menjadikan mereka manusia yang penuh dengan keputusasaan.

5. Dzikrullah bisa menguatkan hati, badan serta memberikan cahaya pada hati dan wajah. Pribadi yang senantiasa mengingat Allah hidupnya tidak akan dipenuhi dengan keluh kesah dan putus asa dalam menghadapi segala sesuatu yang terjadi pada dirinya. Allah menjelaskan dalam al-Qur'an:

"Sesungguhnya manusia itu telah diciptakan dalam kondisi memiliki sifat berkeluh kesah, jika ditimpa dengan berbagai kesusahan atau kesulitan, mudah berkeluh kesah, dan jika mendapatkan kenikmatan, sering kali ia sangat kikir, melainkan bagi orang orang yang mengingat Allah melalui shalat.” (Q.S. Al-Ma'arij: 20 - 22)."

1. Dzikir kepada Allah akan membawa kekuatan hati dan kedamaian jiwa dalam diri seseorang. Karena mereka yang senantiasa mengingat Allah, akan senantiasa diberikan limpahan rahmat kepada dirinya. Sebagaimana dalam hadits Rasulullah Saw bersabda: "Tidaklah suatu kaum mereka berkumpul dalam sebuah majelis yang kondisi mereka mengingat Allah, melainkan para malaikat mengelilingi mereka dan akan dinaungi rahmatnya." (H.R.Ahmad No. 11037).

Maka dzikir sebagai sarana untuk melepaskan belenggu-belenggu kegelisahan, menjauhkan dari keputusasaan, merubah energi-energi negatif menjadi energi positif. Energi negatif seseorang mendorong menjadi manusia yang penuh dengan kepesimisan, mudah mengeluh dan mudah menyerah, sedangkan energi positif akan mendorong manusia untuk berpikir jernih, berpikir optimis, serta memiliki kekuatan jiwa untuk menghadapi berbagai permasalahan yang dihadapi. Karenanya dzikir merupakan sarana untuk menghasilkan energi positif.

Dalam firman Allah Ta'ala: “Orang-orang yang beriman dan hati mereka menjadi tenang dengan mengingat Allah, ingatlah, sesungguhnya dengan mengingat Allah, hati akan menjadi tenang." (Q.S. Ar-Ra'du: 28). “

Ini yang diungkapkan dalam kalimat : واذكر اسم ربك 


\section{Tawakal/Pasrah Hanya Kepada Allah}

Tawakal merupakan buah dari keyakinan. Keyakinan ini yang akan menguatkan keimanan dan keteguhan dalam jiwa seseorang, sehingga ia meyakini bahwa apapun yang diberitakan oleh Nabi saw berkaitan dengan hal yang gaib, mereka sangat meyakininya. Keyakinan ini menghasilkan sikap tawakal kepada Allah, ia menyerahkan semua urusannya hanya kepada Allah. Sikap tawakal bahwa hanya Allah yang bisa mendatangkan manfaat dan yang mampu mencegah bahaya (madharat).

Dalam firman-Nya:

"Siapa yang bertawakal hanya kepada Allah, pasti Allah akan mencukupkan segala keperluannya" (Q.S. Ath-Thalaq: 3)."

Keyakinan dan tawakal ini yang akan mebawa manusia untuk meraih apa yang hendak dituju, baik perkara dunia maupun perkara akhirat. Orang yang tawakal, akan hadir dalam jiwanya ketenangan dan kebahagiaan.

Tawakal merupakan sumber ketenangan dalam menghadapi berbagai masalah sebesar apapun. Nabi Ibrahim Alaihissalam saat harus menghadapi masalah besar dengan raja, sehingga beliau harus dihukum dengan cara dibakar, beliau memasrahkan diri hanya kepada Allah, menyerahkan semua urusan hanya kepada Allah. Saat dirinya dilemparkan pada tumpukan kayu yang siap membakar tubuhnya, beliau pun mengucapkan: "Hasbiyallahu wa ni'mal wakil, ni'mal maula wa ni'mal wakil".

Seperti dalam riwayat Bukhari:

"Dari Ibnu Abbas semoga Allah meridhoinya berkata: ketika Ibrahim dilemparkan ke dalam api yang besar, ucapan terkahir yang beliau ucapkan: "Cukuplah Allah bagiku sebaik-baik tempat memasrahkan diri". (HR. Bukhari No. 4198)."

Dalam riwayat yang lain, Nabi menyampaikan dalam sebuah riwayat:

"Apabila menimpa sebuah urusan besar kepada kalian, maka ucapkan: Cukuplah Allah sebaik-baik tempat untuk berserah diri."

Ini merupkan bentuk penguatan Allah kepada Rasul-ny asaat beliau mesti menghadapi berbagai perkara besar, agar menyerahkan semua urusannya hanya kepada Allah.

\section{Kesabaran}

Sabar secara bahasa artinya menahan. Sedangkan yang dimaksud syari'at, sabar itu menahan jiwa akan tiga hal: pertama, sabar dalam ketaatan kepada Allah, keta'atan kepada Allah seringkali membuat jiwa dan tubuh ini lelah, sehingga saat kelelahan ini datang, manusia memerlukan sabar dalam menjalaninya; kedua, sabar untuk meninggalkan segala hal yang diharamkan Allah, dalam jiwa manusia ada dorongan untuk melakukan keburukan, seperti berbohong, menipu dalam muamalah dengan sesama manusia, sehingga diperlukan kesabaran untuk meninggalkan perbuatan-perbuatan buruk tersebut; dan ketiga, sabar dalam menghadapi takdir Allah yang menyakitkan (Martinelli, 2018).

Pada ayat sebelumnya, Allah memerintahkan kita untuk memasrahkan diri kepadanya diiringi dengan usaha yang semaksimal mungkin. Maka tentu saja kesungguhan dan kesabaran diperlukan dalam mengiringi usaha tersebut, terutama dalam menyampaikan kebaikan. Seringkali dalam menyampaikan dakwah itu, ada orang orang yang menganggap remeh, mencemooh, serta menyakiti baik hati maupun fisik. Karenanya Allah berpesan, dengan perlakuan mereka kepada para penyampai risalah Islam, khususnya khitab ini ditujukan kepada Nabi Muhammad agar beliau bersabar dan meningkatkan kesabaran menghadapi manusia. 
Para penyeru kebaikan mesti memiliki kesabaran dalam menyampaikan risalah Islam kepada kaumnya. Karena tidak semua kaum mau mendengarkan seruannya, bahkan sudah sunnatullah dalam perjalanan dakwah ini akan selalu ada orang-orang yang tidak suka dengan seruan kebaikan, mulai dari diejek, dicemooh, diusir dari kampung halaman karena dituduh sebagai orang yang telah memecah belah persatuan masyarakat, dipenjara, ancaman pembunuhan untuk para pendakwah, bahkan sampai ada nabi yang disembelih oleh kaumnya. Sehingga pada ayat ini, Allah menguatkan nabi-Nya agar bersabar dalam menghadapi kaumnya dan meningkatkan kesabaran, karena seringkali putus asa dan ketergesa-gesaan menjadi penyebab kegagagalan dalam dakwah.

Nabi Yunus 'alaihissalam pun mendapat teguran keras dari Allah Swt karena putus asa dalam dakwah dan meninggalkan kaumnya. Kejahilan masyarakat terhadap dakwah bagi seorang da'I mesti dihadapi dengan kesabaran.

Allah Swt memuji bagi mereka yang senantiasa bersabar:

"Dan sesungguhnya Kami akan memberikan ujian kepada kalian dengan sesuatu dalam bentuk ketakutan, kelapangan, berkurangnya harta, kematian, paceklik dan berbahagialah bagi orangorang yang sabar." (Q.S. Al-Baqarah: 155)."

Allah berfirman:

"Jika Aku memberikan ujian kepada hamba-Ku, berupa penyakit pada kedua matanya, lalu ia bersabar dengan rasa sakitnya itu, maka aku akan menggantikannya dengan surga". (HR. Bukhari No. 5221)."

\section{Keyakinan Akan Janji Allah}

Bagi orang-orang yang beriman, meyakini bahwa apapun yang dilakukan di muka bumi, semua akan dipertanggungjawabkan di hadapan Allah Swt (Rusfi, 2016). Tak ada kebaikan sekecil apapun melainkan pasti akan diperlihatkan dan akan dibalas dengan pahala, begitupun sebaliknya, perbuatan dosa sekecil apapun akan diperlihatkan dan akan dibalas dengan siksaan.

Allah tidak akan pernah mengingkari janji-Nya. Bagi orang-orang yang mengerjakan kebaikan dan mengajak manusia kepada jalan kebaikan, kelak mereka akan dibalas denga pahala yang berlipat ganda dari Allah serta mendapatkan tempat yang mulia di sisi Allah Swt, yaitu surga yang penuh dengan keindahan.

Ayat ini memotivasi secara khusus kepada Rasulullah , dan secara umum kepada kaum muslimin, agar jangan bosan dan putus asa dengan gangguan, ejekan, cemoohan kaumnya kepada kalian, selama kalian menyampaikan kebaikan, karena tak ada yang sia-sia di hadapan Allah Swt:

"Siapa yang melakukan kebaikan sekecil apapun, pasti ia akan melihat pembalasannya, dan siapa yang melakukan kejahatan sekecil apapun, pasti akan mendapatkan balasannya." (Q.S. Al-Zalzalah: $7-8)$.

\section{SIMPULAN}

SD Cendekia Leadership Sshool sudah melakukan langkah-langkah perencanaan yang lengkap dan sistematis yang menghasilkan rumusan-rumusan rencana pendidikan dan pengajaran yang selanjutnya dijadikan acuan pelaksanaan kegiatan pendidikan karakter dan pengajaran yang berbasis Leadership 4H. Terdapat proses pengorganisasian yang disusun secara lengkap dan terperinci mengenai posisi, tugas, tanggungjawab serta mekanisme kerja yang diatur melalui Prosedur Operasi Standar (Standard Operating Procedure). Meski terdapat nomenklatur yang tidak umum dalam penentuan posisi General Manager dalam sebuah Yayasan Pendidikan. Secara keseluruhan pelaksanaan pendidikan karakter dengan 
berbasis Leadership 4H sudah sejalan dengan perencanaan yang ditentukan dan disepakati di awal. Dalam prosesnya pun terdapat pengawasan untuk memastikan bahwa proses pelaksanaan berjalan dengan baik dan tepat. Proses pelaksanaan ini dilakukan secara bertahap dengan tujuan untuk memastikan ketercapaian setiap rencana dalam pelaksanaan secara optimal. Evaluasi diberlakukan bagi seluruh warga sekolah, terutama guru dan peserta didik. Bagi para peserta didik, evaluasi dilaksanakan untuk mengukur ketercapaian akademik serta perkembangan karakter yang dituangkan dalam indikator pencapaian pendidikan karakter dalam Leadership 4H. Selain itu, guru sebagai teladan dievaluasi kinerjanya untuk memastikan bahwa pendidikan karakter dapat membudaya secara baik di lingkungan CLS. Beberapa hambatan dan peluang selalu muncul selama implementasi pengelolaan pendidikan sebagaimana telah diuraikan sebelumnya. SD CLS terus melakukan perbaikan-perbaikan melalui tindak lanjut dari hasil evaluasi secara keseluruhan serta mengimbanginya dengan pemanfaatan peluang-peluang yang dimiliki dan dijumpai selama proses implementasi termasuk mengerahkan beberapa daya dukung yang ada. Secara keseluruhan dalam penelitian ditemukan hasil yang menunjukkan bahwa pendidikan karakter dengan berbasis pendekatan Leadership 4H dapat terlaksana dengan baik, meskipun masih banyak kekurangan-kekurangan yang ditemukan. Hasil ini berdasarkan hasil pengamatan yang dilakukan sebelum, selama, dan pasca penelitian, serta penyebaran angket tingkat kepuasan pelanggan kepada para orang tua siswa lulusan dan yang masih aktif terkait dengan pembudayaan karakter dalam Leadership 4H.

\section{DAFTAR PUSTAKA}

Abdillah, M. A. bin. (2001). Tafsir Hadaiq ar-ruuh wa raihan fii rawabi' ulum al-Qur'an. Lebanon: Dar Thuqu an-najah.

Agung, B., Ramdhani, K., \& Zuhri, M. T. (2020). Konsep Tauhid Sebagai Subtansi Pendidikan Islam: Belajar dari Pengalaman Luqman Al-Hakim dalam Qur'an Surat Lukman Ayat 13. Tarbawiyah Jurnal Ilmiah Pendidikan, 3(2), 271-290.

Khusna, V. N. (2016). Konsep potensi diri manusia (Studi komparasi pemikiran Ibrahim Elfiky dalam buku personal power dan Ary Ginanjar Agustian dalam buku rahasia sukses membangun kecerdasan emosi dan spiritual (ESQ) berdasarkan 6 rukun iman dan 5 rukun islam.). IAIN Ponorogo.

Lumongga, D. R. N. (2016). Depresi: tinjauan psikologis. Kencana.

Martinelli, I. (2018). Menelisik Dimensi Etika Dalam Kegiatan Ekonomi Menurut Perspektif Islam. EduTech: Jurnal Ilmu Pendidikan Dan Ilmu Sosial, 4(1).

Prastowo, A. (2011). Memahami Metode-Metode Penelitian: Suatu Tinjauan Teoritis dan Praktis. Yogyakarta: AR-Ruzz Media.

Putra, S. T. (2019). Psikoneuroimunologi Kedokteran Edisi 2. Airlangga University Press.

Rusfi, M. (2016). Filsafat Harta: Prinsip Hukum Islam Terhadap Hak Kepemilikan Harta. Al-'Adalah, 13(2), 239-258.

Santoso, M. B., Asiah, D. H. S., \& Kirana, C. I. (2018). Bunuh Diri Dan Depresi Dalam Perspektif Pekerjaan Sosial. Prosiding Penelitian Dan Pengabdian Kepada Masyarakat, 4(3), 390-398.

Sugiyono. (2013). Metode Penelitian Pendidikan Pendekatan Kauntitatif, kualitatif dan R\&D. Bandung: Alfabeta.

Yahya, H. (2019). Telaah analisis Imam Ibn Katsir dan A. Quraish Shihab Surah Al-Baqarah Ayat 45 pada tafsir Al-Quran Al-'Azhim dan tafsir Al-Misbah. Universitas Islam Negeri Mataram. 